\title{
The Influence of Inquiry Approach Using Multimedia Toward Students' Concept Mastery And Motivation On The Material of Cell At SMA Labschool Pulau Arar
}

\author{
Sirojjuddin \\ \{sirojjuddin@unimudasorong.ac.id\}
}

Biology Education Department, Universitas Pendidikan Muhammadiyah Sorong

\begin{abstract}
Abstrat. The objectives of inquiry approach using multimedia were (1) to understand to what extent inquiry approach using multimedia influence students' concept mastery of Cell material at SMA Labschool Pulau Arar; (2) to understand to what extent inquiry approach using multimedia influence students' motivation of Cell material at SMA Labschool Pulau Arar; and (3) to the correlation between both concept mastery and motivation. This research applied experimental research which involved 21 students. The data was obtained by pretest and posttest about concept mastery and students' motivation. The obtained data was analyzed using statistical application. There was a significant influence of inquiry approach using multimedia toward students' concept mastery which could be seen on the $t$ value that was higher than $t$ table $(0,981>0,05)$ and contribute $96 \%$. There was a significant influence of inquiry approach using multimedia toward students' motivation that could be seen on the $t$ value which was higher than $t$ table $(0,567>0,05)$ or as $32 \%$.
\end{abstract}

Keywords: inquiry, multimedia, concept mastery, motivation, SMA Labschool Pulau Arar

\section{Background}

The Higher Education Law Number 20 of 2003 stated that Education is a conscious and planned effort to create a learning atmosphere and learning process so that students actively develop their potential to have religious spiritual strength, self-control, personality, intelligence, good character, and the needed skills. In accordance with these instructions, citizens have the same right to obtain quality education, so that the objective of life which is equally mandated in the 1945 Constitution can be achieved.

In 2003 MoNE and MoRA data showed that the School Participation Rate (APS) of the population at aged 7-12 years reached 99.29 percent, the population at aged 13-15 years reached 80.43 percent, and the population at aged 16-18 years reached 50.65 percent. In the same year the gross enrollment rate (APK) of SD / MI / SDLB reached 114.53 percent, APK of SMP / MTs / SMPLB reached 78.43 percent, APK for SMA / SMK / MA / MAK reached 48.79 percent and APK PT reached 14.25 percent.

For the Papua region, the APS of the population at aged 7-12 is the lowest among other 
provinces in Indonesia, consisted of men 83.94 percent, and women 82, 74 percent. In the West Papua region, the population APS was slightly higher, for men aged 7-12 years was 94.91 percent, and women was 91,72 percent.

APK for elementary school / MI / SDLB in the Papua region reached 102, 98 percent (for men), and 97, 36 percent (for women), APK for SMP / MTs / SMPLB 71.10 percent (male), 67.75 percent (female). APK for SMA / MA / SMK 49, 62 percent (male), and 47, 65 percent (female).

Whereas in the West Papua region APK SD / MI / SDLB 119, 36 percent (male), 117, 45 percent (female), APK of SMP / MTs / SMPLB 64.34 percent (male), 60.49 percent ( women), SMA / MA / SMK APK 54.34 percent (male) and 47, 66 percent (female). From the APS and APK above, it is clear that the provinces of Papua and West Papua are below that of other provinces.

The Human Development Index (HDI) for 2011 in Papua province was only $65.36 \%$ and West Papua 69, 65\% (Source: Gender-based Human Development in 2005-2012, BPS collaboration with the Ministry of Women's Empowerment and Child Protection)

SMA Labschool Pulau Arar was the only high school in Arar Island, Mayamuk District, Sorong Regency, West Papua Province. The learning process in SMA Labschool Pulau Arar was still conventional. The majority of teachers or educators still used the lecturing method. This led to the influence of students' concept mastery.

The ability of students' concepts mastery depended on the learning process provided by the teacher itself. This was in line with the definition of learning. The above statement was in accordance with Education Law No. 20 of 2003, which stated that learning was the process of interaction among students, educators and learning resources in a learning environment. This was also in line with the KBBI, 2008: 30, that was learning was a process of how to make people learn. Based on the definition above, a learning must be established between teachers/ educators and students. Learning biology in SMA Labschool Pulau Arar Island was still conventional whereas a good learning often involved learning media.

Media was a tool that functioned to convey a message (Bovee, 1997). Learning media was a tool that served to convey learning messages. Learning was a process of communication among learners, instructors and teaching materials. Communication would not work without the help of means of delivering messages or media (Ouda Teda Ena: 2000).

Good learning media must meet several requirements. Learning media must increase learner motivation. Using learning media aimed at providing motivation to learners. In addition, the media must also stimulate learners to remember what they have learned in addition to providing new learning stimuli. Good media would also enable learners to provide responses, feedback and also encouraged students to practice correctly.

There were several criteria for assessing the effectiveness of a media. Hubbard proposed nine criteria to assess media (Hubbard, 1983). The first criteria were about cost. Costs must indeed be assessed by the results that would be achieved by using the media. Other criteria were the availability of supporting facilities such as electricity, compatibility with class size, conciseness, ability to change, time and energy preparation, the effect caused, complexity and the latter was usability. The more learning goals could be achieved by a media, the better the media was.

The above criteria tended to be conventional media. Thorn proposes six criteria for assessing interactive multimedia (Thorn, 1995). The first assessment criterion is easy to operate. A program must be designed as simply as possible so language learners do not need to learn computers first. The second criterion was the content of cognition, the other criteria were knowledge and presentation of information. These two criteria were to assess the content 
of the program itself, whether the program has met the learning needs of the learner or not. The fourth criterion was media integration where the media must integrate language aspects and skills that must be learned. To attract the interest of learners, the program must have an artistic appearance, thus the aesthetics was also have to be considered. The last assessment criterion was the overall function. The program developed must provide the learning desired by the learner. Therefore, when someone finished running a program he would feel he has learned something. In SMA Labschool Pulau Arar, there were many teachers who did not maximize the use of learning media both visually and audio-visual, so this led to the low of students' concept mastery, abilities of inquiry and students attitudes toward the subjects taught were not implemented optimally.

Based on the explanation above, the researcher was interested in studying the influence of inquiry approach using multimedia toward students' concept mastery and motivation on the discussion of cell at SMA Labschool Pulau Arar. It was expected that inquiry approach using multimedia could give positive impact on education in SMA Labschool Pulau Arar and education in West Papua.

\section{Research Method}

\subsection{Research Design}

This research applied experimental research design. The independent variable of this research was inquiry approach using multimedia, while the dependent variable was students' concept mastery and motivation.

Students' concept mastery was assessed by giving written test about concepts discussed during teaching learning process. The test result was numerical score which would be compared between pretest and posttest score. The improved score would be analyzed using NGain. N-Gain showed to what extent the improvement on students' concept mastery before treatment and after treatment applied. Meanwhile, to obtain the data on students' motivation, the researcher used questionnaire.

\subsection{Population and Sample}

The population in this research was the whole students of SMA Labschool Pulau Arar, while the sample was XI grade students consisted of 21 students, 10 males and 11 females.

\subsection{Identification and Operational Definition}

Variables used in this research were $\mathrm{X}, \mathrm{Y} 1$ and $\mathrm{Y} 2$. In this research, the independent variable $(\mathrm{X})$ was inquiry approach using multimedia and the dependent variables $(\mathrm{Y})$ were students' concept mastery (Y1) and motivation (Y2).

\subsection{Research Instrument}

Research instrument used were questionnaire and test. Questionnaire used to get the data on students' motivation and test was used to get data on students' concept mastery. The test was divided into two, pretest and posttest. 


\subsection{Technique of Analyzing The Data}

In this research, the researcher used these techniques:

a. Validity Test

Validity test in this research used correlation formula of Pearson Product Moment (PPM.

$$
r_{\text {value }}=\frac{n(\Sigma X Y)-(\Sigma X) \cdot(\Sigma Y)}{\sqrt{\left\{n \cdot \Sigma X^{2}-(\Sigma X)^{2}\right\} \cdot\left\{n \cdot \Sigma Y^{2}-\left(\Sigma Y Y^{2}\right\}\right.}}
$$

b. Reliability Test

Realiability test aimed at finding the fixed form of instrument. The formula used was Spearmean Brown

$$
r_{11}=\frac{2 . r b}{1+r_{b}}
$$

c. Normality Test

This test aimed to prove whether the obtained data was normal or not. The formula used to test this normality was Chi-Square.

$$
x^{2}=\sum_{i=1}^{k} \frac{(f o-f e)^{2}}{f e}
$$

d. Homogeneity Test

This test used to prove whether the obtained data was homogeny or not. The homogeneity test used was Bartlet formula.

\section{Finding and Discussion}

\subsection{Result of Basic Analysis Test}

1. Instrument Test

a. Normality Test

Normality test was used to test whether the researched sample normal or not. Based on the measurement by SPSS18.00, it could be understand that the significant value was normal. The distribution of the normality test was as follow:

Table 1 The Data of Normality Test

\begin{tabular}{lcl}
\hline \multicolumn{1}{c}{ Variable } & Significant Value & Result \\
\hline Concept mastery & $0,110 \geq 0,05$ & Normal \\
\hline Inquiry approach using multimedia & $0,895 \geq 0,05$ & Normal \\
\hline Motivation & $0,873 \geq 0,05$ & Normal \\
\hline
\end{tabular}

b. Homogeneity Test

Homogeneity test used was Bartlet formula. This test aimed to know the homogeneity level. The result of homogeneity test was as follow: 
Table 2. Homogeneity Test

\begin{tabular}{lcl}
\hline \multicolumn{1}{c}{ Variable } & Significant Value & Result \\
\hline Concept mastery & $0,970 \geq 0,05$ & Homogen \\
\hline Inquiry approach using multimedia & $0,504 \geq 0,05$ & Homogen \\
\hline Motivation & $0,952 \geq 0,05$ & Homogen \\
\hline
\end{tabular}

Based on the table above, it can be concluded that those three variables were homogeny.

c. Validity and Reliability Test

The objective of validity test was to obtain the valid data about inquiry approach, the students' concept mastery, and students' motivation that combined to be inquiry approach using multimedia.

The instrument used in this research was questionnaire with 25 questions to test the influence of inquiry approach using multimedia, 30 multiple choice questions to test concept mastery and 42 questions of questionnaire to test students' motivation.

The result of validity and reliability tests on questionnaire (X) showed that of 25 questions, there were 15 items invalid and not reliable. Thus there were 10 items were valid and reliable. Based on 30 items of concept mastery instruments (Y1), 15 items were valid and reliable. Meanwhile, of 42 items on students' motivation, there were 20 items valid and reliable.

Table 3. Reliability of Test Instrument

\begin{tabular}{c|c}
\hline \multicolumn{2}{c}{ Reliability Statistics } \\
\hline Cronbach's Alpha & N of Items \\
\hline 0,547 & 30 \\
\hline
\end{tabular}

Based on the table above, the reliability of the instrument used was high, that was 0,547 on the range of $0,40-0,599$.

Table 4. Reliability of Inquiry Approach Using Multimedia Instrument

\section{Reliability Statistics}

\begin{tabular}{|c|c|}
\hline Cronbach's Alpha $^{\mathrm{a}}$ & N of Items \\
\hline 0,875 & 25 \\
\hline
\end{tabular}

Based on the table above, the reliability of the instruments used was very high, that was 0,875 on the range of $0,80-1,000$.

Table 5. Reliability of Students' Motivation Instrument

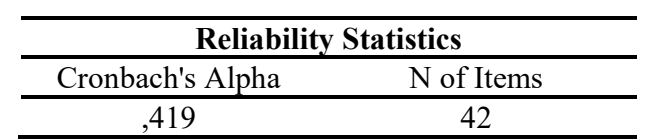

Based on the table above, the reliability of the instruments used was high, that was 0,419 on the range of $0,40-0,599$.

Based on the result of the tables above, it could be concluded that the instruments could be used in this research. 


\subsection{Data Analysis}

a. Correlation Analysis of $\mathrm{X}$ toward $\mathrm{Y}_{1}$

The influence of inquiry approach using multimedia (X) toward students' concept mastery (Y1) was measured using Pearson Correlation on SPSS Program. Here was the result:

Table 6. Correlation Analysis of X toward Y1

\begin{tabular}{llrr}
\hline \multicolumn{4}{c}{ Correlations } \\
\hline & \multicolumn{1}{c}{$\mathrm{X}$} & \multicolumn{1}{c}{$\mathrm{Y}_{1}$} \\
\hline $\mathrm{X}$ & Pearson Correlation & 1 &, 981 \\
\cline { 2 - 4 } & Sig. (2-tailed) & 23 &, 005 \\
\cline { 2 - 4 } & $\mathrm{N}$ &, 981 & 23 \\
\hline $\mathrm{Y}_{1}$ & Pearson Correlation &, 005 & \\
\cline { 2 - 4 } & Sig. (2-tailed) & 23 & 23 \\
\cline { 2 - 4 } & $\mathrm{N}$ & &
\end{tabular}

Based on the data, the value of coefficient correlation between variable $X$ and variable Y1 was high, that was 0,981 . The nul correlation could be seen on the value of its probability on the Sig bar. The probability was the same as the Sig $(0,005 \leq 0,005)$, which meant there was correlation between those two variables.

Moreover, to state the significance of $\mathrm{X}$ variable toward $\mathrm{Y} 1$ variable could be defined with determinant formula KP $=\mathrm{r} 2 \times 100 \%$, or $0,9812 \times 100 \%=96 \%$ while the rest, $4 \%$, was determined by other variable.

b. Correlation Analysis of X toward Y2

The influence of inquiry using multimedia (X) toward students' motivation (Y2) was measured using Pearson correlation on SPSS Program and the result was as follow:

Table 7. Correlation Analysis of X toward Y2

\begin{tabular}{|c|c|c|c|}
\hline \multicolumn{4}{|c|}{ Correlations } \\
\hline & & $\mathrm{X}$ & Y2 \\
\hline \multirow[t]{3}{*}{$\mathrm{X}$} & Pearson Correlation & 1 & ,567 \\
\hline & Sig. (2-tailed) & & ,004 \\
\hline & $\mathrm{N}$ & 23 & 23 \\
\hline \multirow[t]{3}{*}{$\mathrm{Y}_{2}$} & Pearson Correlation & ,567 & 1 \\
\hline & Sig. (2-tailed) &, 004 & \\
\hline & $\mathrm{N}$ & 23 & 23 \\
\hline
\end{tabular}

The data above had explained that the coefficient correlation of both variables was high, that was 0,567 and the probability value was under $0,005(0,004 \leq 0,005)$. Thus, it could be concluded that there was correlation between both variables. Furthermore, to state the significance of $\mathrm{X}$ toward $\mathrm{Y} 2$ variables could be defined with determinant formula $\mathrm{KP}=$ $\mathrm{r} 2 \times 100 \%$, atau $0,5672 \times 100 \%=32 \%$, while the rest, $68 \%$, was determined by other variable.

c. Correlation Analysis of X, Y1, and Y2 Variables

To know the correlation among the three variables, inquiry approach using multimedia (X), students' concept mastery (Y1) and students' motivation (Y2), it was analyzed used 
PPM correlation, where it was tested among $\mathrm{X}$ variable toward $\mathrm{Y} 1, \mathrm{X}$ variable toward $\mathrm{Y} 2$, and Y1 toward Y2. The result of those three tests could be seen in the table below:

Table 8 Correlation Analysis X toward Y1

\begin{tabular}{llrr}
\hline \multicolumn{4}{c}{ Correlations } \\
\hline & \multicolumn{1}{c}{$\mathrm{X}$} & \multicolumn{1}{c}{ Y1 } \\
\hline $\mathrm{X}$ & Pearson Correlation & 1 &, 981 \\
\cline { 2 - 4 } & Sig. (2-tailed) & 23 &, 005 \\
\cline { 2 - 4 } & $\mathrm{N}$ &, 981 & 23 \\
\hline Y1 & Pearson Correlation &, 005 & 1 \\
\cline { 2 - 4 } & Sig. (2-tailed) & 23 & 23 \\
\cline { 2 - 4 } & $\mathrm{N}$ &
\end{tabular}

Tabel 9. Correlation Analysis X toward Y2.

\begin{tabular}{llrr}
\hline \multicolumn{4}{c}{ Correlations } \\
\hline & \multicolumn{1}{c}{$\mathrm{X}$} & \multicolumn{1}{c}{ Y2 } \\
\hline $\mathrm{X}$ & Pearson Correlation & 1 &, 567 \\
\cline { 2 - 4 } & Sig. (2-tailed) & &, 004 \\
\cline { 2 - 4 } & $\mathrm{N}$ & 23 & 23 \\
\hline Y2 & Pearson Correlation &, 567 & 1 \\
\cline { 2 - 4 } & Sig. (2-tailed) &, 004 & \\
\cline { 2 - 4 } & $\mathrm{N}$ & 23 & 23 \\
\hline
\end{tabular}

Those two tables showed that the value of coefficient correlation was higher than $\alpha=$ $0,05(0,981 ; 0,567 \geq 0,05)$

d. Concept Mastery Analysis

In this analysis, the researcher had summarized several data using microsoft excel, here was as follow:

Table 10. Analysis of Pretest, Posttest, and N Gain of Concept Mastery

\begin{tabular}{cccc}
\hline Average of Pretest & Average of Postest & Average of N Gain & Result \\
\hline 6.286667 & 8.433333 & 0.633333 & Medium \\
\hline
\end{tabular}

The result above also showed that there were students who have low N-Gain. It was due the influence of teaching model used by the teacher and also $\mathrm{X}$ factor. The $\mathrm{X}$ factor could be internal or external condition of the students.

The researcher's statement was in line with the statement of Sujana (2005:39), that was: Factors influencing the learning result were: 1) Students' internal factor (it could be students' ability in analyzing learning process, students' learning motivation, interest, attention, learning habit, physical and psychological factors), 2) External factor which covered environment and teaching quality. Meanwhile, according to Caroll (in Sujana, 2005:40) learning result was influenced by five factors, these were: learning talent, time availability for learning, time availability for explaining the material, teaching quality and students ability. The statement above was supported by Djamarah in Aunurahman, 
(2010:115) It was motivation that the students could be intrigued to learn with their friends in order to reach success.

Sudirman AM, (in Sobri : 2010) stated that learning motivation was a non intellectual psychological factor. Learning motivation took an important role in establishing learning desire, learning pleasure and learning eagerness. In learning activity, motivation was a whole booster for students to learn which guarantee the learning continuity so that the learning objective of every student could be achieved. The researcher interpreted the above explanation in a concept mastery diagram below:

\section{CONCEPT MASTERY ON LESSON PLAN 1 BASED ON N GAIN}

- Rendah $\quad$ Sedang Tinggi

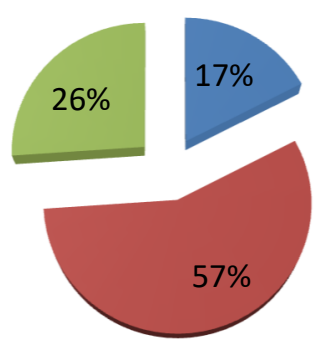

Fig 1. Students' concept mastery on lesson plan 1 based on N-Gain

\section{CONCEPT MASTERY ON LESSON PLAN 1 BASED ON N} GAIN
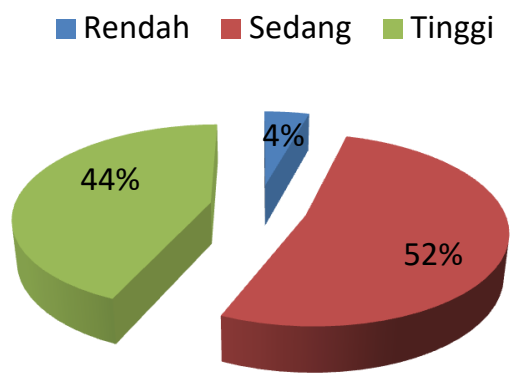

Fig 2. Students' concept mastery on lesson plan 2 based on N-Gain 


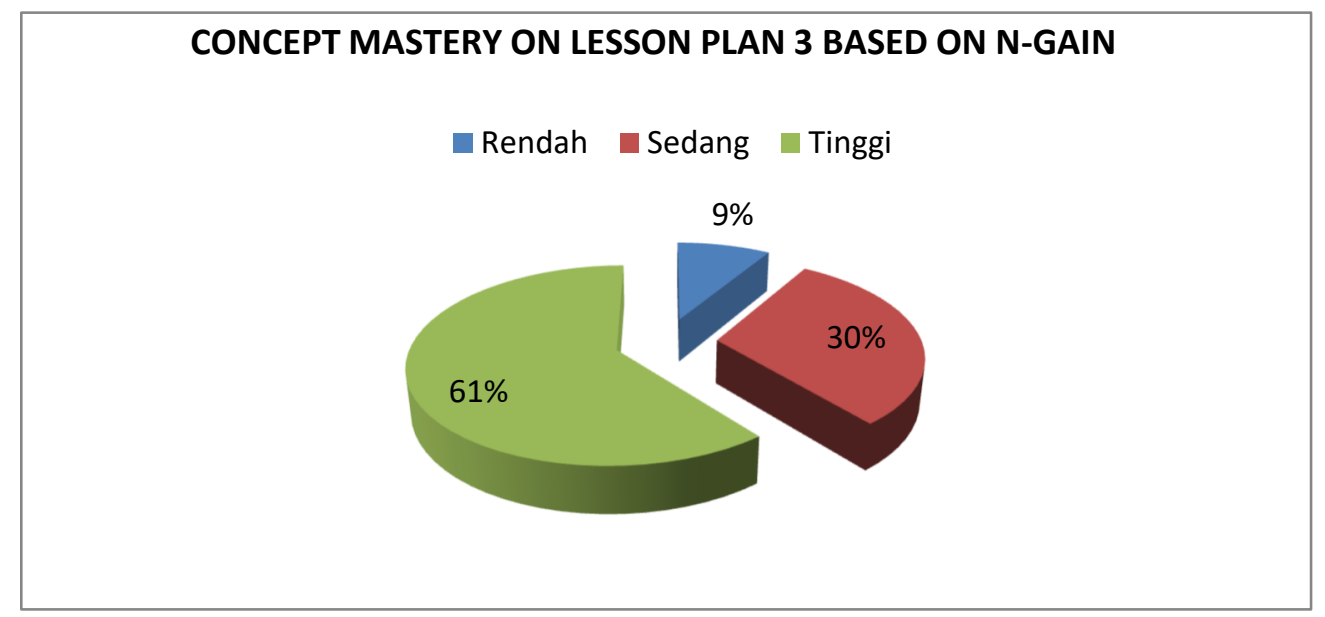

Fig 3 Students' concept mastery on lesson plan 3 based on N-Gain

Table 11. The distribution of minimum and maximum score, average score of pretest and posttest, and N-Gain in every lesson plan

\begin{tabular}{|l|c|c|r|r|r|r|r|r|r|}
\hline \multirow{2}{*}{$\begin{array}{c}\text { Scor } \\
\text { e }\end{array}$} & \multicolumn{3}{|c|}{ RPP 1 } & \multicolumn{3}{|c|}{ RPP 2 } & \multicolumn{3}{c|}{ RPP 3 } \\
\cline { 2 - 10 } & $\begin{array}{c}\text { Pre } \\
\text { Test }\end{array}$ & $\begin{array}{c}\text { Post } \\
\text { Test }\end{array}$ & $\begin{array}{c}\text { N } \\
\text { Gain }\end{array}$ & $\begin{array}{c}\text { Pre } \\
\text { Test }\end{array}$ & $\begin{array}{c}\text { Post } \\
\text { Test }\end{array}$ & $\begin{array}{c}\text { N } \\
\text { Gain }\end{array}$ & $\begin{array}{c}\text { Pre } \\
\text { Test }\end{array}$ & $\begin{array}{c}\text { Post } \\
\text { Test }\end{array}$ & $\begin{array}{c}\text { N } \\
\text { Gain }\end{array}$ \\
\hline Max & 7,3333 & 9,333 & 0,86 & 6,67 & 9,33 & 0,83 & 6,67 & 9,3 & 0,83 \\
\hline Min & 5,3333 & 6,667 & 0,29 & 5,33 & 7,33 & 0,2 & 4,67 & 7,3 & 0,33 \\
\hline Rt & 6,3333 & 8 & 0,57 & 6 & 8,33 & 0,52 & 5,67 & 8,3 & 0,58 \\
\hline
\end{tabular}

Based on the table and diagram above, it clearly explained that the concept mastery was improved significantly.

\subsection{Discussion}

a. Inquiry Approach using Multimedia Influenced toward Students Concept Mastery

Inquiry approach using multimedia could be one of approaches in teaching learning process. It was proved that inquiry approach using multimedia had a significant influence toward educational process at school.

A theory, stated that teaching learning process was teacher centered, was indisputable when a teacher used inquiry approach using multimedia. In the process, teacher was only became a facilitator functioning at assisting students to find out they way to master the concept in learning process.

This research focuses on the creativity of students in finding a learning concept where by using the inquiry approach using multimedia students are invited to find problems and solve them based on the concepts they receive. This is supported by previous research that stated inquiry learning is a learning method that instills the basics of scientific thinking in students, so that in this learning process students learn more by themselves, develop creativity in solving problems. So students are really placed as learning subjects (Sanjaya: 2012) 
Florentina Widihastrini (2009) stated that the inquiry procedures were: 1) formulating a problem, 20 collecting the data through observation, 3) analyzing the obtained data and presenting it, and 4) communicating the result in front of the class in discussion.

In learning process which discussed about cell, students were required to be able to know about cell and its characteristics. Inquiry approach using multimedia was considered to be appropriated approach to improve concept mastery. It was in line with the result of correlation analysis which showed that there was a relevant correlation of inquiry approach using multimedia toward concept mastery (see table 4.11).

\section{b. Inquiry Approach using Multimedia was Influenced toward Students' Motivation}

It was found that there was a significant influence between inquiry approaches through multimedia on student motivation. This was in line with the theory proposed by Pujadi (2007) that students' learning motivation could be defined as a condition in students that encouraged and directed their behavior to achieve their goals in education. Ideally, the aim of students in attending education was to master the subject they learnt.

The results of Sarjono's (2000) study (in R. Witarsa: 2011) stated that science learning was not done through scientific inquiry but was dominated by information transfer activities and was memorized, so that science learning outcomes were low and not meaningful.

Another study conducted by Hendra Cipta (2008) (in R. Witarsa: 2011) about the emergence of inquiry components in the implementation of science learning, showed that there was a significant relationship between the design of inquiry learning and the teacher's ability to bring up components of inquiry in the implementation of science learning.

The growth of students' motivation to study well needed to be supported by good and quality learning methods. This was consistent with the fact that a teacher often used conventional methods, and learning process was only teacher centered. Students tended to not pay attention to the material presented, even tended to be sleepy or seek teacher attention to play.

The inquiry approach provided motivation for students to be able to find material concepts desired by the teacher, so that by this approach students were invited to get used to learning right.

In the learning process discussing cell, where students were required to be able to see the real structure of cell, inquiry approach using multimedia gave significant motivation. The students were more interested in finding any information about cell. It was relevant with the analysis of inquiry approach using multimedia (X) toward students' motivation (Y2) where there was significant influence of $\mathrm{X}$ variable toward (Y2) variable.

\section{c. Inquiry Approach using Multimedia toward Students' Concept Mastery and Motivation}

A student could master a concept if only the teacher could use more innovative teaching approach. It was proved that there was a significant relation between them and its correlation contribution was $96 \%$.

Motivation could be seen as a series of reaction starting from there was a need then there appear a desire to fulfill that need so that it created psychological tension that led to satisfaction (Pujadi, 2007). The theory was in line with this research result; there was significant correlation of inquiry approach using multimedia toward students' motivation as much as $32 \%$. 
Students' motivation produced great influence toward students' concept mastery. It was proved that when a student has a high motivation in learning, he would master the concept taught by the teacher well. The theory was in line with this result where the concept mastery was influenced by students' motivation in learning. The co-efficient of its correlation was 0 , $313(0,313>0,05)$, it influenced $9,7 \%$ to it.

Therefore, it could be concluded that inquiry approach using multimedia toward students' concept mastery and motivation. Moreover, students' motivation also influenced the concept mastery.

\section{d. Concept Mastery}

Through inquiry approach using multimedia, the students' mastery of concept on the material of cell at XI grade showed that there was an improvement on pretest and posttest in every meeting.

On 1 st meeting (lesson plan 1), the average of $\mathrm{N}$-Gain was 0,54 which categorized as medium and on 2nd meeting (lesson plan 2), the average of N-Gain was 0,675 which was categorized as medium. Meanwhile, on the 3rd meeting (lesson plan 3), the average of N-Gain was 0,7 which categorized as advance. Thus, it could be concluded that the inquiry approach using multimedia toward concept mastery was influenced positively.

\section{Conclusion}

Based on the research problem, result analysis and the discussion, it could be concluded that:

1. There is significant influence of inquiry approach using multimedia toward concept mastery of students by 96 percent.

2. There is significant influence of inquiry approach using multimedia toward students' motivation by 32 percent.

\section{Reference}

[1] 2003. Standar Kompetensi mata pelajaran Biologi SMA dan MA. Jakarta. Departemen Pendidikan Nasional.

[2] Aunurrahman,S. 2010. Belajar dan Pembelajarn Bandung: Alfabeta.

[3] Azhar Arsyad. 2002. Media Pembelajaran. Jakarta : Raja Grafindo Persada.

[4] BPS : 2012. Pembangunan Manusia berbasis Gender Tahun 2005-20012,

[5] Denzin, Norman K. Dan Lincoln S. Yvonna. . Hanbook Of Qualitatve Reseach.

[6] Fajri, Zul EM, Senja, RA. __. Kamus Lengkap Bahasa Indonesia. __. . Difa Publisher

[7] Hamalik. 1994. Media Pendidikan. Bandung : Sinar Baru

[8] Jatmiko, N,A. 2006. Pengaruh Sikap Wajib Pajak pada Pelaksanaan Sanksi DendaPelayanan Fiskusdan Kesadaran Perpajakan terhadap kepatuhan wajib pajak (Studi Empiris terhadap wajib pajak orang pribadi di kota semarang). Tesis. Diterbitkan.Semarang. Undip.

[9] Kusnandar. 2004. Metode Statistik Dan Aplikasinya Dengan Minitab Dan Excel. Yoyakarta. Madyan Press.

[10] Latuheru. 1988. Media Pembelajaran Dalam Proses Belajar Mengajar Masa Kini. Jakarta : Depdikbud.

[11] Partino, Sugondo. 2007. Pengantar Statistik. Yogyakarta. Pustaka mahasiswa. 
[12] Ramadhani, Neila. . Sikap dan Perilaku. : Dinamika Psikologi Mengenai Perubahan Sikap dan Perilaku. Yogyakarta. UGM Press.

[13] Riduan. 2009. Pengantar Statistik Sosial. Bandung. Alvabeta.

[14] Riduan. 2010. Metode dan Teknik Menyusun Tesis . Bandung. Alfabeta.

[15] Soetomo. 1993. Dasar-Dasar Interaksi Belajar Mengajar. Surabaya : Usaha Nasional

[16] Sriyati, Siti. Penelitian Tindakan Kelas.Makalah. Jurusan Pendidikan Biologi FMIPA UPI.

[17] Sudarman, Danim. 1995. Media Komunikasi Pendidikan. Jakarta : Bumi Aksara.

[18] Sugiyono. 1999. Statistik untuk Penelitian. Bandung. Alfabeta.

[19] Sujana, Nana. 2005. Dasar-dasar Proses Belajar Mengajar. Bandung: Sinar Baru

[20] Suryati, Nurmina. 2013. Perbedaan Keterampilan Berpikir Kritis dan prsetasi belajar dengan menggunakan pendekatan pemecahan masalah pada pembelajran larutan penyangga kelas XI IPA SMA Negeri 1 Sentani. Tesis. Universitas Cenderawasih

[21] Tim Penyusun.2013. Panduan Akademik dan Penulisan Tesis. Program Pascasarjana Magister Pendidikan IPA. Universitas Cenderawasih.

[22] Yusri, Ghazali. Sikap Pelajar terhadap Pembelajaran Kemahiran Lisan bahasa Arab di Universiti Teknologi MARA (UiTM). Gema Online ${ }^{\mathrm{TM}}$ Journal of Luangage of StudiesVolume.10(3)2013.

[23] Pujadi, Arko. 2007. Faktor_faktor yang Mempengaruhi Motivasi Belajar Mahasiswa: Studi Kasus Pada Fakultas Ekonomi Universitas Bunda Mulia.Business dan management Journal Bunda Mulia, Vol: 3, No. 2, September 2007

[24] Witarsa, Ramadhan. 2011. Analisis kemampuan Guru yang sudah tersertifikasidan belum tersertifikasi dalam pembelajaran Sains di SD. ISSN:1412-565X. Edisi Khusus, No. 2, Agustus 2011.

[25] Oka, A.A._. Peneingkatan Aktivitas Belajar dan Penguasaan Konsep Ekosistem Melalui Pembelajaran Kontekstual di SMA Teladan 1 Metro. Jounal Pendidikan.

[26] Ghulam, H., Agustina, L. 2011. Pengaruh Motivasi Belajar Terhadap Prestasi Belajar IPA di Sekoalh Dasar. Jurnal Penelitian Pendidikan. Vol. 12, No. 1, April 2011.

[27] Gatot Pramono. 2008. Pelatihan pemanfaatan TIK Untuk pembelajaran Tingkat nasional tahun 2008, Pemanfaatan Multimedia Pembelajaran. Modul. Pusat Teknologi Informasi dan Komunikasi PendidikanDepartemen Pendidikan Nasional.

[28] Umrotun. 2012. Peningkatan Kemampuan Pemahaman Konsep Optik Melalui Tekhnik Inkuiri Terbimbing Perserta Didik Kelas VIII Semester Genap tahun Ajaran 2011/2012.Jurnal Penelitian Pembelajaran Fisika.ISSN 2086-2407. Vol.3. No.1 April 2012.

[29] Indrawan, M,I dkk. 2013. Pengembangan Multimedia Interaktif berbasis Inkuiri Untuk Pembelajaran Komputer Grafis bagi Siswa Dasin Komunikasi Visual di SMK. E-Journal Program pascasarjana Universitas Pendidikan GaneshaProgram Studi tekhnologi Pembelajaran. Volume 3 Tahun 2013. 